\title{
Sprinkle and Trickle Irrigation System Design Using Tapered Pipes for Pressure Loss Adjusting
}

\author{
Mohammad Valipour ${ }^{1}$ \\ ${ }^{1}$ Irrigation and Drainage Engineering College, College of Abureyhan, University of Tehran, Pakdasht, Tehran, \\ Iran \\ Correspondence: Mohammad Valipour, Irrigation and Drainage Engineering College, College of Abureyhan, \\ University of Tehran, Pakdasht, Tehran, Iran. Tel: 98-212-630-0812. E-mail: vali-pour@hotmail.com
}

Received: August 30, 2012 Accepted: September 12, 2012 Online Published: November 15, 2012

doi:10.5539/jas.v4n12p125 URL: http://dx.doi.org/10.5539/jas.v4n12p125

\begin{abstract}
Accurate computing of amount of pressure loss is very important in sprinkle and trickle irrigation system design. Not correctly adjusted of pressure loss are causes lack of appropriate performance or failure of sprinkle and trickle irrigation system. By tapered pipes, pressure loss adjusted using increasing or decreasing of pressure head. In this study using HydroCalc software, ability of single and tapered pipes in pressure loss adjusting has been compared. Single and tapered laterals were able to adjusting of pressure loss but single manifolds were not able to achieving to the desired pressure head. In single lateral-tapered manifold system due to the lower pressure loss in laterals, can be use from several types of pipe diameters for manifolds but in tapered lateral-tapered manifold system due to the more pressure loss in laterals, the choice is limited. The best diameters for tapered manifolds with single lateral were $69.2-36.8 \mathrm{~mm}, 69.2-58.2-36.8 \mathrm{~mm}$, and 58.2-46.0-36.8 $\mathrm{mm}$ whereas the best diameters for tapered manifold with tapered lateral were $69.2-46.0-36.8 \mathrm{~mm}$.
\end{abstract}

Keywords: HydroCalc software, pressure head, pressure loss, tapered pipe, sprinkle manifold design, trickle manifold design

\section{Introduction}

Many tries have been done to appropriate design of sprinkle and trickle irrigation system, which some of them will be described in the following.

Molina-Martínez and Ruiz-Canales (2009) evaluated drip irrigation lateral diameters with on-line emitters using a Pocket PC software. As results, it showed with a figure with light emitting diodes (LED), the commercial diameters that could be used. Other results implemented in this tool were the maximum and minimum pressures for each diameter and a table that showed, on a comparative basis, whether the pressure tolerance of every diameter was exceeded or not. Bresler (1977) presented principles and application of trickle-drip irrigation o soil-water management. Lesikar, Weynand and Persyn (2004) evaluated the application uniformity of subsurface drip distribution systems in difference pressures. He showed that low operating pressures might be attributed to design and/or installation problems. Rareş (2009) designed a drip irrigation system using HydroCalc irrigation planning. He found that the use of HydroCalc allows the designer, dealer or end-user to evaluate the performance of micro irrigation in-field components, such as: Drip laterals and micro sprinklers, Sub mains and manifolds, Main lines (PVC, PE, etc.), Valves Energy calculation. Reynolds, Yitayew and Petersenc (1995) designed low-head bubbler irrigation systems. They showed that these systems could operate at pressures as low as $1 \mathrm{~m}(3.3$ $\mathrm{ft}$ ). Zapata, Playánb and Martínez-Cobb (2007), presented a contribution to the design of collective pressurized irrigation networks in solid-set sprinkler-irrigated windy areas successfully. Jackson and Kay (1987) used of pulse irrigation for reducing clogging problems in trickle emitters. A laboratory study on a sandy loam soil has demonstrated that pulsed flows up to three times the equivalent continuous flow can be used with little change to the soil wetting pattern. Yazar, Sezen and Sesveren (2002) studied LEPA and trickle irrigation of cotton in the Southeast Anatolia Project (GAP) area in Turkey. The research results revealed that both the trickle and LEPA irrigation systems could be used successfully for irrigating cotton crop under the arid climatic conditions of the GAP area in Turkey. Colombo and Oron (2006) designed and managed a tool for trickle irrigation using plant water accessibility function (PWA). Simulated values and field observed values were in good agreement, demonstrating the potential usefulness of the proposed PWA function as a design and management tool for trickle 
irrigation systems. Oron (1982) presented technical and economic considerations in the design of closed conduit irrigation systems. Valiantzas (2003 \& 2005), designed microirrigation submain units using tapered manifold and laterals. The design variables were the lengths of two given pipe sizes for the laterals as well as the appropriate lengths of the available pipe sizes for the manifold. Tapered laterals and manifold were selected in such a way that the sum of the costs of the laterals and the manifold is minimized, while the hydraulic design criterion was ensured. The case of a single-diameter lateral with tapered manifold pipeline was also examined. The design procedure could be also applied in sprinkle irrigation tapered laterals. Valiantzas and Dercas (2005) analyzed multidiameter center-pivot sprinkler laterals. A comparison test with a numerical stepwise method indicated that the proposed analytical approach was sufficiently accurate for practical applications. Provenzano, Pumo and Di Dio (2005) evaluated head loss in drip irrigation laterals. Relative errors on the pressure head estimation for the examined cases were always $\pm 2.4 \%$, and therefore the proposed methodology could serve for a quick, approximate evaluation of the total head loss along the laterals. Valiantzas (2008) in other research presented a power formula for the Carcy-Weisbach pipe flow equation. The usefulness of the formula was demonstrated in an application concerning the optimal design of a delivery pipeline with pumping. The power form of the friction formula facilitates the formulation of the problem leading to the derivation of a simple equation from which the economic diameter was explicitly calculated. Kale, Singh and Mahar (2008) designed pressurized irrigation subunit as optimal. The verification of operating inlet pressure head obtained by the proposed model with accurate numerical step-by-step method suggested that it was mostly accurate. Martí, Provenzano, Royuela and Palau-Salvador (2010) predicted integrated emitter local loss using artificial neural networks successfully. Anwar (1999) presented an adjusted factor for pipelines with multiple outlets and outflow. He claimed that this factor might find application in the design of tapered sprinkle and trickle irrigation pipelines. Sepúlveda, Zazueta, Vergot and Bucklin (2005) used handheld computers for hydraulic calculations of microirrigation subunits. They presented an intermediate correction factor was developed that allows computation of head loss between any two points of a multiple outlet line. Sammis, Williams and Wu (1990) developed a trickle irrigation scheduling model successfully.

Appropriate design of sprinkle and trickle irrigation system studied in many previous researches but in none of them pressure loss has not been adjusted using the best selection of diameters and lengths for single and tapered pipes. In this paper, using HydroCalc software pressure loss adjusted for sprinkle and trickle irrigation system and the best diameters and lengths have been determined for both single and tapered pipes.

\section{Materials and Methods}

In this study used from HydroCalc software for sprinkle and trickle irrigation system design. Tables 1 and 2 shows input data for lateral and manifold design, respectively.

Table 1. Input data for lateral design

\begin{tabular}{cccccccccc}
\hline Emitter & Type & $\begin{array}{c}\mathrm{J} \\
(\mathrm{m} / 100 \mathrm{~m})\end{array}$ & $\begin{array}{c}\mathrm{S}_{\mathrm{e}} \\
(\mathrm{m})\end{array}$ & $\begin{array}{c}\text { Pipe } \\
\text { Material }\end{array}$ & $\begin{array}{c}\text { Pressure Rating } \\
(\mathrm{bar})\end{array}$ & $\begin{array}{c}\mathrm{Q} \\
(\mathrm{L} / \mathrm{h})\end{array}$ & $\begin{array}{c}\mathrm{L} \\
(\mathrm{m})\end{array}$ & $\begin{array}{c}\text { End Pressure } \\
(\mathrm{m})\end{array}$ & $\begin{array}{c}\text { Calculation } \\
\text { Method }\end{array}$ \\
\hline $\begin{array}{c}\text { On } \\
\text { Line }\end{array}$ & $\begin{array}{c}\text { MULTI OUTLET } \\
\text { DRIPPER }\end{array}$ & -0.1 & 1 & PE pipe & 2.5 & 4 & 100 & 10 & $\begin{array}{c}\text { Emitter Line } \\
\text { Length }\end{array}$ \\
\hline
\end{tabular}

Table 2. Input data for manifold design

\begin{tabular}{|c|c|c|c|c|c|c|c|}
\hline $\mathrm{J}(\mathrm{m} / 100 \mathrm{~m})$ & $\mathrm{N}_{1}$ & Pipe Type & Pipe Class (bar) & Friction Factor & $\mathrm{L}(\mathrm{m})$ & Pressure Head $(\mathrm{m})$ & Formula for Computation \\
\hline-0.1 & 30 & PE pipe & 4 & 150 & 600 & 35 & Darcy-Weisbach \\
\hline
\end{tabular}

In HydroCalc software flow rate variation and emission uniformity are calculated as follows (Gilary, 2008):

$$
\begin{gathered}
F V=100\left[\left(Q_{\max }-Q_{\min }\right) / Q_{\max }\right] \\
E U=100\left(Q_{\min } / Q_{\max }\right)\left[1-1.27 \mathrm{CV} / \mathrm{n}^{1 / 2}\right]
\end{gathered}
$$

Where $F V$ is flow rate variation (\%), $Q_{\max }$ is the maximum discharge of emitters (L/h), $Q_{\min }$ is the minimum discharge of emitters (L/h), $E U$ is emission uniformity (\%), $C V$ is coefficient of variation of discharge rates, and $n$ is number of emitter for each plant. 
Usually, single laterals are used, because they are convenient to install and maintain, but tapered laterals may be less expensive (Keller \& Bliesner, 1990). Tapered laterals are sometimes used on steep slopes where the increase in pressure from the slope would result in too much pressure at the end (SCS, 1991).

For tapered laterals, pipe friction head loss $\left(h_{f}\right)$ in lateral must be computed in a three-step process (Keller \& Bliesner, 1990):

Step I-Computing $h_{f}$ by follow equation for the full length of the lateral that has the larger diameter pipe.

$$
h_{f}=J^{\prime} F L / 100
$$

Where $h_{f}$ is pipe friction head loss (m), $F$ is reduction coefficient to compensate for the discharge along the pipe, $L$ is length of the lateral $(\mathrm{m})$, and $J$ ' is equivalent head loss gradient of the lateral with emitters $(\mathrm{m} / 100 \mathrm{~m})$ as follows:

$$
J^{\prime}=J\left(S_{e}+f_{e}\right) / S_{e}
$$

Where $S_{e}$ is spacing between emitter connections along the lateral $(\mathrm{m}), f_{e}$ is emitter connection loss as an equivalent length of lateral $(\mathrm{m})$, and $J$ is head loss gradient $(\mathrm{m} / 100 \mathrm{~m})$ as follows:

$$
J=100 h_{f} / L=K Q^{1.75} / D^{4.75}
$$

Where $K$ is constant, $7.89 \times 10^{7}$ for metric units for water at $20^{\circ} \mathrm{C}, Q$ is flow rate $(\mathrm{L} / \mathrm{s})$, and $D$ is inside diameter of pipe (mm).

Step II-Computing $h_{f}$ values for both the large- and the small-diameter pipes for a lateral length equal to the length of small-diameter pipe and determine the difference between these values.

Step III-The $h_{f}$ for the tapered lateral will equal the $h_{f}$ found in step I plus the difference in the two $h_{f}$ values found in step II.

\section{Results and Discussion}

Table 3 shows obtained results for lateral design.

Table 3. Obtained results for lateral design

\begin{tabular}{ccccccccccccc}
\hline Lateral Type & $\mathrm{D}(\mathrm{mm})$ & $\mathrm{L}(\mathrm{m})$ & $\mathrm{KD}$ & Exponent & $\begin{array}{c}\text { Pressure } \\
\mathrm{Head}(\mathrm{m})\end{array}$ & $\mathrm{V}(\mathrm{m} / \mathrm{s})$ & Total Emitters & Qavg $(\mathrm{L} / \mathrm{h})$ & Qin $(\mathrm{L} / \mathrm{h})$ & $\mathrm{FV}(\%)$ & $\mathrm{EU}(\%)$ \\
\hline Single & 28.8 & 100 & 0.06 & 0.48 & 10.07 & 0.17 & 100 & 4.00 & 400.35 & 0.33 & 96.11 \\
Tapered & $17.4-13.6$ & $60-40$ & $0.17-0.45$ & 0.48 & 11.00 & $0.47-0.31$ & 100 & 4.06 & 406.27 & 4.37 & 94.71 \\
\hline
\end{tabular}

For on line emitter there are four choices to select inside diameter (28.8. 22.2, 17.4, and $13.6 \mathrm{~mm})$. According to the table 3 if there is not a budget problem, an inside diameter equal to $28.8 \mathrm{~mm}$ due to the minimum of pressure loss $(7 \mathrm{~cm})$ is the best state for single lateral design. Otherwise, for reducing the costs a tapered lateral that make from inside diameters equal to 17.4 and $13.6 \mathrm{~mm}$ and lengths equal to 60 and $40 \mathrm{~m}$ for each diameter, respectively, is the best choice. In this state amount of pressure loss is 1.00 meter. Figures 1 and 2 shows pressure head in length of single and tapered lateral, respectively.

Table 4. Obtained results for manifold design in single lateral-single manifold system

\begin{tabular}{cccc}
\hline $\mathrm{D}(\mathrm{mm})$ & $\mathrm{L}(\mathrm{m})$ & End Pressure $(\mathrm{m})$ & $\mathrm{V}(\mathrm{m} / \mathrm{s})$ \\
\hline 101.6 & 600 & 34.60 & 0.41 \\
83.0 & 600 & 33.94 & 0.62 \\
69.2 & 600 & 32.46 & 0.89 \\
58.2 & 600 & 29.14 & 1.26 \\
46.0 & 600 & 16.81 & 2.01 \\
\hline
\end{tabular}




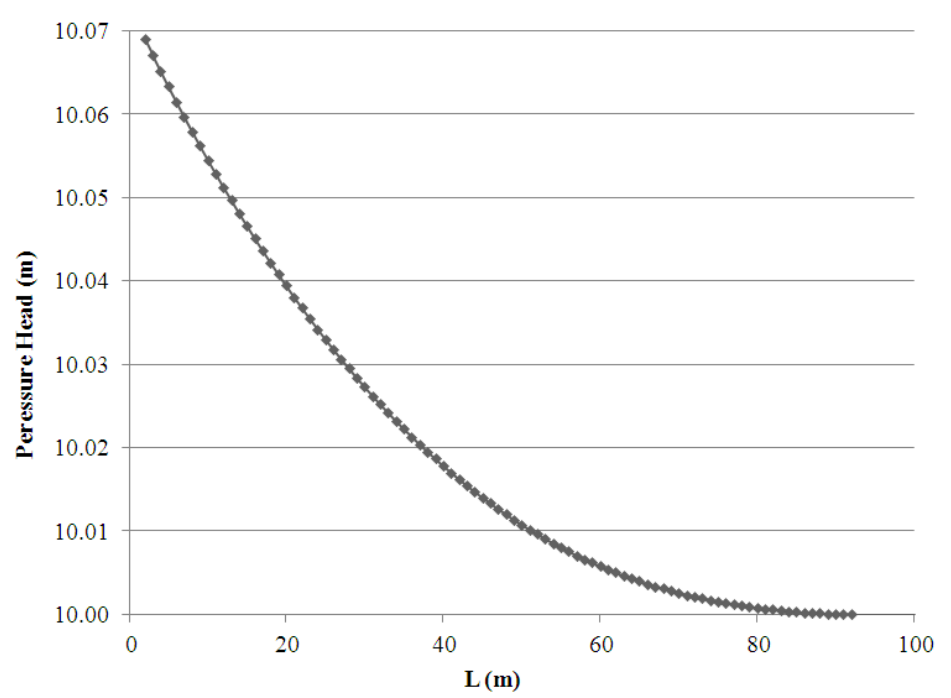

Figure 1. Pressure head in length of single lateral

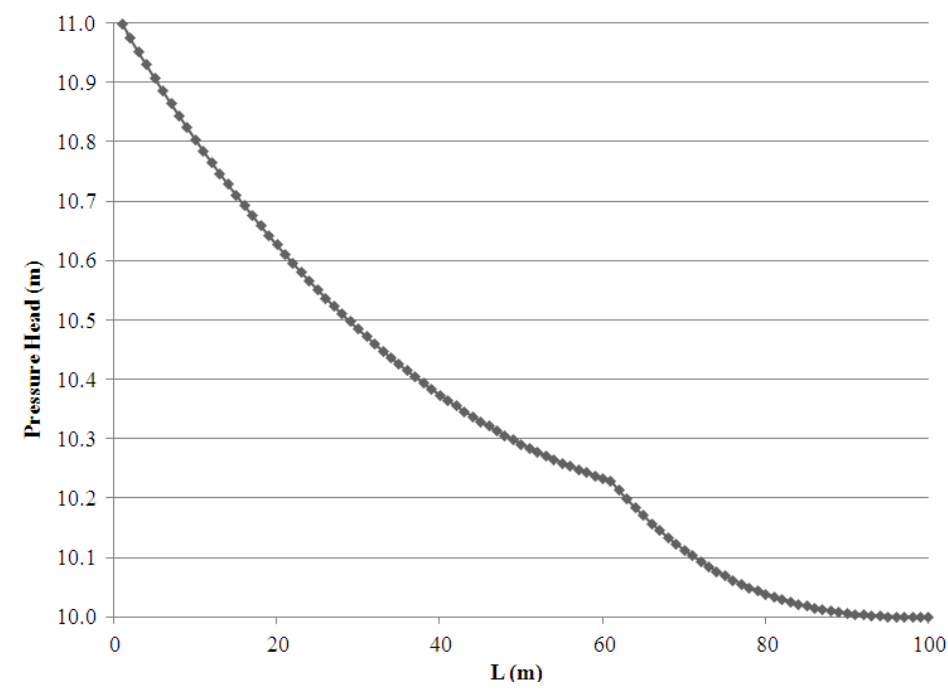

Figure 2. Pressure head in length of tapered lateral

Table 5. Obtained results for manifold design in tapered lateral-single manifold system

\begin{tabular}{cccc}
\hline $\mathrm{D}(\mathrm{mm})$ & $\mathrm{L}(\mathrm{m})$ & End Pressure $(\mathrm{m})$ & $\mathrm{V}(\mathrm{m} / \mathrm{s})$ \\
\hline 101.6 & 600 & 34.59 & 0.42 \\
83.0 & 600 & 33.92 & 0.63 \\
69.2 & 600 & 32.39 & 0.90 \\
58.2 & 600 & 28.98 & 1.27 \\
46.0 & 600 & 16.32 & 2.04 \\
\hline
\end{tabular}

In figure 2 amount of pressure head decreases with greater intensity in second pipe (small diameter). Tables 4 and 5 shows obtained results for manifold design in single lateral-single manifold system and tapered lateral-single manifold system, respectively.

For manifold design, there are 11 choices to select inside diameter $(101.6,83.0,69.2,58.2,46.0,36.8,27.2,21.2$, $17.0,13.2$, and $9.8 \mathrm{~mm}$ ). According to the tables 4 and 5 amount of end pressure in none of inside diameters has not reached the desired value (10.07 and $11.0 \mathrm{~m})$. In addition, if using smaller diameters, amount of pressure head is 
lower than 10.07 and $\mathrm{m}$ in manifold and are not suitable for manifold design. The velocity should be limited to about $2 \mathrm{~m} / \mathrm{s}$ in manifolds (SCS, 1991) and in HydroCalc software should be limited to $2.5 \mathrm{~m} / \mathrm{s}$ (Gilary, 2008). Table 6 shown obtained results for manifold design in single lateral-tapered manifold system. In tapered manifold for adequate flushing, the diameter of the smallest pipe should be no less than one-half that of the largest pipe (SCS, 1991). Thus according to the diameter of lateral is $28.8 \mathrm{~mm}$ the smallest pipe is $36.8 \mathrm{~mm}$ and two diameters 101.6 and 83.0 are not suitable. After combining remained four diameters, table 6 shows that three combinations are suitable due to the closest amount of end pressure $(10.08 \mathrm{~m})$ to required pressure head of single lateral $(10.07 \mathrm{~m})$. Figures 3, 4, and 5 shows pressure head in these three combinations. In figure 3 amount of pressure head decreases with greater intensity in second pipe $(457 \mathrm{~m})$ and in figures 4 and 5 amount of pressure head decreases with greater intensity in third pipe (440 and $404 \mathrm{~m})$. Table 7 shown obtained results for manifold design in tapered lateral-tapered manifold system. In this system due to the higher pressure loss in tapered lateral there is only one appropriate choice (69.2-46.0-36.8 $\mathrm{mm})$.

Table 6. Obtained results for manifold design in single lateral-tapered manifold system

\begin{tabular}{cccc}
\hline $\mathrm{D}(\mathrm{mm})$ & $\mathrm{L}(\mathrm{m})$ & End Pressure $(\mathrm{m})$ & $\mathrm{V}(\mathrm{m} / \mathrm{s})$ \\
\hline $69.2-36.8$ & $143-457$ & 10.08 & $0.89-2.30$ \\
$69.2-58.2-36.8$ & $80-80-440$ & 10.08 & $0.89-1.09-2.30$ \\
$58.2-46.0-36.8$ & $98-98-404$ & 10.08 & $1.26-1.67-2.09$ \\
$69.2-58.2-36.8$ & $102-50-448$ & 10.09 & $0.89-1.00-2.30$ \\
$69.2-46.0-36.8$ & $50-151-399$ & 10.09 & $0.89-1.81-1.99$ \\
$69.2-36.8$ & $144-456$ & 10.12 & $0.89-2.30$ \\
$69.2-46.0-36.8$ & $111-50-439$ & 10.14 & $0.89-1.61-2.20$ \\
$69.2-36.8$ & $145-455$ & 10.17 & $0.89-2.30$ \\
$69.2-46.0-36.8$ & $50-155-395$ & 10.19 & $0.89-1.81-1.99$ \\
$46.0-36.8$ & $261-339$ & 10.21 & $2.01-1.67$ \\
$58.2-46.0-36.8$ & $100-100-400$ & 10.22 & $1.26-1.70-2.09$ \\
$46.0-36.8$ & $265-335$ & 10.29 & $2.01-1.67$ \\
$69.2-46.0-36.8$ & $50-160-390$ & 10.32 & $0.89-1.81-1.99$ \\
$46.0-36.8$ & $270-330$ & 10.39 & $2.01-1.67$ \\
$69.2-36.8$ & $150-450$ & 10.42 & $0.89-2.30$ \\
$69.2-58.2-36.8$ & $110-50-440$ & 10.49 & $0.89-1.00-2.30$ \\
$69.2-46.0-36.8$ & $120-50-430$ & 10.58 & $0.89-1.61-2.20$ \\
$58.2-36.8$ & $161-439$ & 10.62 & $1.26-2.20$ \\
$58.2-36.8$ & $162-438$ & 10.66 & $1.26-2.20$ \\
$58.2-46.0-36.8$ & $50-171-379$ & 10.71 & $1.26-1.81 .1 .88$ \\
$58.2-36.8$ & $165-435$ & 10.78 & $1.26-2.20$ \\
$58.2-46.0-36.8$ & $50-175-375$ & 10.80 & $1.26-1.81 .1 .88$ \\
$69.2-46.0-36.8$ & $91-91-418$ & 10.85 & $0.89-1.67-2.09$ \\
$58.2-46.0-36.8$ & $50-180-370$ & 10.92 & $1.26-1.81 .1 .88$ \\
$58.2-36.8$ & $170-430$ & 11.00 & $1.26-2.20$ \\
$58.2-46.0-36.8$ & $131-50-419$ & 11.09 & $1.26-1.54-2.09$ \\
$69.2-46.0-36.8$ & $95-95-410$ & 11.15 & $0.89-1.67-2.09$ \\
$58.2-46.0-36.8$ & $125-50-425$ & 11.25 & $1.26-1.54-2.09$ \\
$69.2-58.2-36.8$ & $50-111-439$ & 11.41 & $0.89-1.13-2.20$ \\
$69.2-58.2-36.8$ & $50-113-437$ & 11.49 & $0.89-1.13-2.20$ \\
$69.2-46.0-36.8$ & $100-100-400$ & 11.53 & $0.89-1.67-2.09$ \\
$69.2-58.2-36.8$ & $50-115-435$ & 11.58 & $0.89-1.13-2.20$ \\
$46.0-36.8$ & $300-300$ & 11.59 & $2.01-1.57$ \\
$69.2-58.2-36.8$ & $60-105-435$ & 11.62 & $0.89-1.13-2.20$ \\
$69.2-46.0-36.8$ & $50-180-370$ & 11.71 & $0.89-1.81-1.88$ \\
$69.2-58.2-36.8$ & $50-120-430$ & 11.79 & $0.89-1.13-2.20$ \\
$69.2-58.2-36.8$ & $50-130-420$ & 12.21 & $0.89-1.13-2.20$ \\
$69.2-58.2-36.8$ & $90-80-430$ & 12.27 & $0.89-1.05-2.20$ \\
$69.2-58.2-36.8$ & $100-70-430$ & 12.31 & $0.89-1.05-2.20$ \\
$58.2-46.0-36.8$ & $110-110-380$ & 12.38 & $1.26-1.61-1.99$ \\
$69.2-46.0-36.8$ & $50-200-350$ & 12.98 & $0.89-1.81-1.78$ \\
$58.2-36.8$ & $200-400$ & 13.64 & $1.26-2.09$ \\
$69.2-58.2-36.8$ & $100-100-400$ & 14.95 & $0.89-1.05-2.09$ \\
$46.0-36.8$ & $400-200$ & 15.07 & $2.01-1.05$ \\
\hline & & &
\end{tabular}




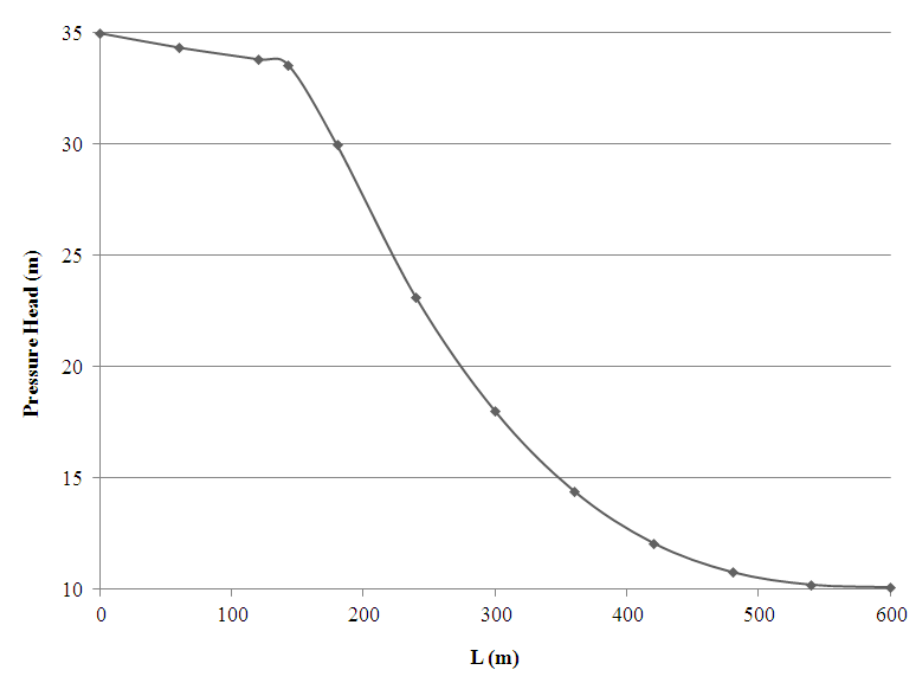

Figures 3. Pressure head for a tapered manifold $(69.2-36.8 \mathrm{~mm})$ in single lateral-tapered manifold system

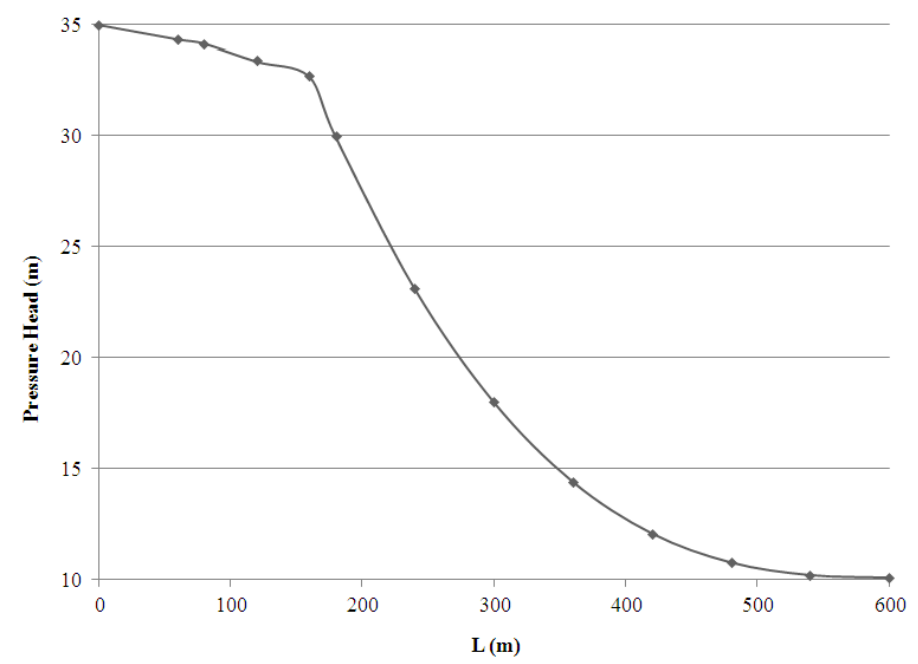

Figures 4. Pressure head for a tapered manifold $(69.2-58.2-36.8 \mathrm{~mm})$ in single lateral-tapered manifold system

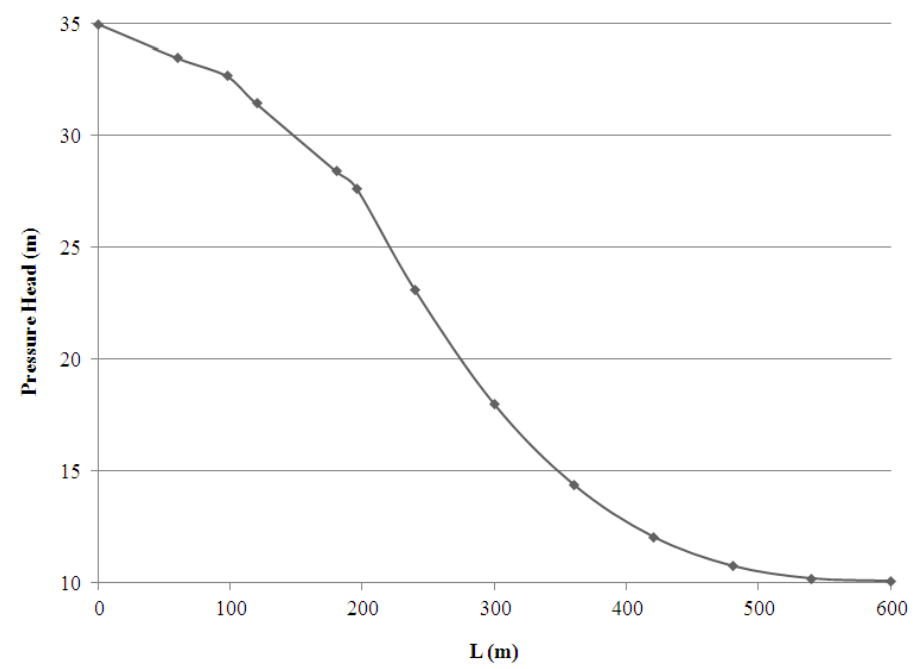

Figures 5. Pressure head for a tapered manifold (58.2-46.0-36.8 mm) in single lateral-tapered manifold system 


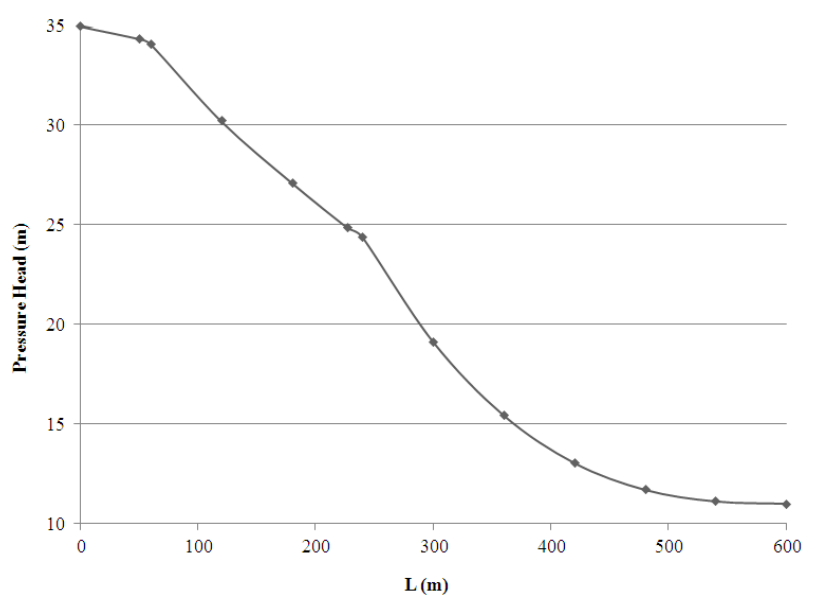

Figures 6. Pressure head for a tapered manifold (69.2-46.0-36.8 mm) in tapered lateral-tapered manifold system

Figure 6 shows pressure head for this choice. In Figure 6 amount of pressure head decreases with greater intensity in third pipe (373 m).

Table 7. Obtained results for manifold design in tapered lateral-tapered manifold system

\begin{tabular}{cccc}
\hline $\mathrm{D}(\mathrm{mm})$ & $\mathrm{L}(\mathrm{m})$ & End Pressure $(\mathrm{m})$ & Velocity $(\mathrm{m} / \mathrm{s})$ \\
\hline $69.2-46.0-36.8$ & $50-177-373$ & 11.02 & $0.90-1.84-1.91$ \\
$69.2-46.0-36.8$ & $50-178-372$ & 11.04 & $0.90-1.84-1.91$ \\
$69.2-46.0-36.8$ & $130-50-420$ & 11.04 & $0.90-1.56-2.23$ \\
$69.2-46.0-36.8$ & $50-179-371$ & 11.07 & $0.90-1.84-1.91$ \\
$69.2-58.2-36.8$ & $50-118-432$ & 11.08 & $0.90-1.15-2.23$ \\
$69.2-46.0-36.8$ & $50-180-370$ & 11.09 & $0.90-1.84-1.91$ \\
$69.2-58.2-36.8$ & $50-119-431$ & 11.12 & $0.90-1.15-2.23$ \\
$69.2-58.2-36.8$ & $50-120-430$ & 11.16 & $0.90-1.15-2.23$ \\
$58.2-46.0-36.8$ & $101-101-398$ & 11.16 & $1.27-1.63-2.02$ \\
$69.2-58.2-36.8$ & $81-81-438$ & 11.27 & $0.90-1.06-2.23$ \\
$58.2-46.0-36.8$ & $141-50-409$ & 11.33 & $1.27-1.50-2.12$ \\
$69.2-58.2-36.8$ & $50-125-425$ & 11.38 & $0.90-1.15-2.23$ \\
$58.2-46.0-36.8$ & $50-191-359$ & 11.38 & $1.27-1.84-1.81$ \\
$58.2-46.0-36.8$ & $105-105-390$ & 11.43 & $1.27-1.63-2.02$ \\
$69.2-58.2-36.8$ & $111-50-439$ & 11.49 & $0.90-1.02-2.23$ \\
$58.2-46.0-36.8$ & $50-199-351$ & 11.55 & $1.27-1.84-1.81$ \\
$46.0-36.8$ & $301-299$ & 11.57 & $2.04-1.49$ \\
$58.2-46.0-36.8$ & $50-200-350$ & 11.58 & $1.27-1.84-1.81$ \\
$69.2-58.2-36.8$ & $50-130-420$ & 11.60 & $0.90-1.06-2.23$ \\
$69.2-58.2-36.8$ & $70-105-425$ & 11.63 & $0.90-1.10-2.23$ \\
$46.0-36.8$ & $305-295$ & 11.64 & $2.04-1.49$ \\
$69.2-58.2-36.8$ & $90-80-430$ & 11.65 & $0.90-1.06-2.23$ \\
$69.2-58.2-36.8$ & $100-70-430$ & 11.70 & $0.90-1.06-2.23$ \\
$58.2-46.0-36.8$ & $150-50-400$ & 11.70 & $1.27-1.50-2.12$ \\
$46.0-36.8$ & $310-290$ & 11.72 & $2.04-1.49$ \\
$58.2-46.0-36.8$ & $110-110-380$ & 11.77 & $1.27-1.63-2.02$ \\
$69.2-58.2-36.8$ & $120-50-430$ & 11.92 & $0.90-1.02-2.23$ \\
$69.2-36.8$ & $161-439$ & 12.03 & $0.90-2.23$ \\
$69.2-36.8$ & $162-438$ & 12.08 & $0.90-2.23$ \\
$69.2-36.8$ & $165-435$ & 12.22 & $0.90-2.23$ \\
$58.2-36.8$ & $181-419$ & 12.31 & $1.27-2.12$ \\
$58.2-36.8$ & $162-438$ & 12.35 & $1.27-2.12$ \\
$58.2-36.8$ & $161-439$ & 12.39 & $1.27-2.12$ \\
$69.2-46.0-36.8$ & $50-200-350$ & 12.39 & $0.90-1.84-1.81$ \\
$69.2-36.8$ & $170-430$ & 12.45 & $0.90-2.23$ \\
$58.2-36.8$ & $185-415$ & 12.47 & $1.27-2.12$ \\
$69.2-46.0-36.8$ & $120-50-410$ & 12.60 & $0.90-1.56-2.12$ \\
$69.2-46.0-36.8$ & $101-101-398$ & 12.65 & $0.90-1.63-2.02$ \\
$69.2-46.0-36.8$ & $105-105-390$ & 12.94 & $0.90-1.63-2.02$ \\
$58.2-36.8$ & $200-400$ & 13.06 & $1.27-2.12$ \\
$46.0-36.8$ & $350-250$ & 13.27 & $2.04-1.27$ \\
$69.2-46.0-36.8$ & $100-100-400$ & 13.30 & $0.90-1.63-2.02$ \\
$69.2-58.2-36.8$ & $100-100-400$ & 14.41 & $0.90-1.06-2.12$ \\
$46.0-36.8$ & $400-200$ & 14.53 & $2.04-1.06$ \\
\hline & & &
\end{tabular}




\section{Conclusions}

In this study using HydroCalc software, ability of single and tapered pipes in pressure loss adjusting has been compared. Single and tapered laterals were able to adjusting of pressure loss but single manifolds were not able to achieving to the desired pressure head. In single lateral-tapered manifold system due to the lower pressure loss in laterals, can be use from several types of pipe diameters for manifolds but in tapered lateral-tapered manifold system due to the more pressure loss in laterals, the choice is limited.

\section{Abbreviations}

$F V=$ Flow rate variation $(\%)$

$Q_{\max }=$ Maximum discharge of emitters $(\mathrm{L} / \mathrm{h})$

$Q_{\min }=$ Minimum discharge of emitters $(\mathrm{L} / \mathrm{h})$

$E U=$ Emission uniformity (\%)

$C V=$ Coefficient of variation of discharge rates

$n=$ Number of emitter for each plant

$h_{f}=$ Pipe friction head loss (m)

$F=$ Reduction coefficient to compensate for the discharge along the pipe

$L=$ Length of the lateral (m)

$J^{\prime}=$ Equivalent head loss gradient of the lateral with emitters $(\mathrm{m} / 100 \mathrm{~m})$

$S_{e}=$ Spacing between emitter connections along the lateral (m)

$f_{e}=$ Emitter connection loss as an equivalent length of lateral (m).

$J=$ Head loss gradient $(\mathrm{m} / 100 \mathrm{~m})$

$K=$ Constant, $7.89 \times 10^{7}$ for metric units for water at $20^{\circ} \mathrm{C}$

$Q=$ Flow rate $(\mathrm{L} / \mathrm{s})$

$D=$ Inside diameter of pipe (mm)

$N_{l}=$ Number of laterals

$K D=$ Coefficient related to the emitter type

Exponent $=$ Coefficient related to the emitter type

\section{References}

Anwar, A. A. (1999). Adjusted Factor $G_{a}$ For Pipelines With Multiple Outlets and Outflow, Journal of Irrigation and Drainage Engineering, November/December 1999, 355-359. Retrieved from http://colleges.ksu.edu.sa/Papers/Papers/GaFactorforPipelines.pdf

Bresler, E. (1977). Trickle-Drip Irrigation: Principles and Application to Soil-Water Management, Advances in Agronomy, 29, 343-393. http://dx.doi.org/10.1016/S0065-2113(08)60222-9

Colombo, A., \& Oron, D. (2006). Plant water accessibility function: A design and management tool for trickle irrigation, Agricultural Water Management, 82(1-2), 45-62. http://dx.doi.org/10.1016/j.agwat.2005.07.025

Gilary, E. (2008). HydroCalc Irrigation Planning User Manual. Israel: NETAFIM Corporation.

Jackson, R. C., \& Kay, M. G. (1987). Use of pulse irrigation for reducing clogging problems in trickle emitters, $\begin{array}{llll}\text { Journal of Agricultural Engineering Research, 37(3-4), 223-227. } & \end{array}$ http://dx.doi.org/10.1016/S0021-8634(87)80019-7

Kale, R. V., Singh, R. P., \& Mahar, P. S. (2008). Optimal Design of Pressurized Irrigation Subunit. Journal of Irrigation and Drainage Engineering, 134(2), 137-146. http://10.1061/(ASCE)0733-9437(2008)134:2(137)

Keller, J., \& Bliesner, R. D. (1990). Sprinkle And Trickle Irrigation, Van Nostrand Reinhold, New York, ISBN: 0-442-24645-5.

Lesikar, B. J., Weynand, V. L., \& Persyn, R. A. (2004). Evaluation of the Application Uniformity of Subsurface Drip Distribution Systems (pp. 73-83). In K. R. Mankin (Ed.). Wastewater Treatment X, Conference Proceedings (Number 701P0104). Sacramento, California, USA: ASAE Publication. Retrieved from http://www.netafimusa.com/files/applications/.../ASAE-2004-Paper-1.pdf 
Martí, P., Provenzano, G., Royuela, Á., \& Palau-Salvador, G. (2010). Integrated Emitter Local Loss Prediction Using Artificial Neural Networks. Journal of Irrigation and Drainage Engineering, 136(1), 11-22. http://10.1061/(ASCE)IR.1943-4774.0000125

Molina-Martínez, J. M., \& Ruiz-Canales, A. (2009). Pocket PC software to evaluate drip irrigation lateral diameters with on-line emitters, Computers and Electronics in Agriculture, 69(1), 112-115. http://dx.doi.org/10.1016/j.compag.2009.06.006

Oron, G. (1982). Technical and economic considerations in the design of closed conduit irrigation systems: A case study. Agricultural Water Management, 5(1), 15-27. http://dx.doi.org/10.1016/0378-3774(82)90035-X

Provenzano, G., Pumo, D., \& Di Dio, P. (2005). Simplified Procedure to Evaluate Head Loss in Drip Irrigation Laterals. Journal of Irrigation and Drainage Engineering, 131(6), 525-532. http://dx.doi.org/10.1061/(ASCE)0733-9437(2005)131:6(525)

Rareş, H. C. Z. (2009). Designing A Drip Irrigation System Using Hydrocalc Irrigation Planning. Research Journal of Agricultural Science, 41(1), 420-425. Retrieved from http://agricultura.usab-tm.ro/Simpo2009pdf/Simpo\%202009\%20vol\%201/Sectiunea\%204/04\%20Halbac\% 20Cotoara\%20Zamfir\%20Rares\%201.pdf

Reynolds, C., Yitayew, M. \& Petersenc, M. (1995). Low-head bubbler irrigation systems. Part I: Design, Agricultural Water Management, 29(1), 1-24. http://dx.doi.org/10.1016/0378-3774(95)01188-9

Sammis, T. W., Williams, S. \& Wu, I. P. (1990). Development of a trickle irrigation scheduling model, Computers and Electronics in Agriculture, 5(3), 187-196. http://dx.doi.org/10.1016/0168-1699(90)90010-M

SCS. (1991). National Engineering Handbook, United States Department of Agriculture, Soil Conservation Service. Section 15: Irrigation, Chapter 7: Trickle Irrigation, 2nd Edition, 210-VI, NEH 15-7.

Sepúlveda, E. S., Zazueta, F. S., Vergot, P., \& Bucklin, R. A. (2005). Use of Handheld Computers for Hydraulic Calculations of Microirrigation Subunits (pp. 25-28). July 2005, Vila Real, Portugal. Retrieved from http://www.efita.net/apps/accesbase/bindocload.asp?d=5780\&t=0\&identobj=RMZ8sDWg\&uid=57305290 $\& \mathrm{sid}=57 \& \mathrm{idk}=1$

Valiantzas, J. D. (2003). Closure to "Explicit Hydraulic Design of Microirrigation Submain Units with Tapered Manifold and Laterals" by John D. Valiantzas. Journal of Irrigation and Drainage Engineering, 131(3), 299-300. http://10.1061/(ASCE)0733-9437(2005)131:3(299.2)

Valiantzas, J. D. (2003). Explicit Hydraulic Design of Microirrigation Submain Units with Tapered Manifold and Lateral. Journal of Irrigation and Drainage Engineering, 129(4), 227-236. http://10.1061/(ASCE)0733-9437(2003)129:4(227)

Valiantzas, J. D. (2003). Explicit Power Formula for the Carcy-Weisbach Pipe Flow Equation: Application in Optimal Pipeline Design. Journal of Irrigation and Drainage Engineering, 134(4), 454-461. http://dx.doi.org/10.1061/(ASCE)0733-9437(2008)134:4(454)

Valiantzas, J. D., \& Dercas, N. (2005). Hydraulic Analysis of Multidiameter Center-Pivot Sprinkler Laterals, Journal of Irrigation and Drainage Engineering, 131(2), 137-146. http://dx.doi.org/10.1061/(ASCE)0733-9437(2005)131:2(137)

Yazar, A., Sezen, S. M., \& Sesveren, S. (2002). LEPA and trickle irrigation of cotton in the Southeast Anatolia Project (GAP) area in Turkey. Agricultural Water Management, 54(3), 189-203. http://dx.doi.org/10.1016/S0378-3774(01)00179-2

Zapata, N., Playánb, E., Martínez-Cobb, A., Sáncheza, I., Facia, J. M., \& Lecinac, S. (2007). From on-farm solid-set sprinkler irrigation design to collective irrigation network design in windy areas, Agricultural Water Management, 87(2), 187-199. http://dx.doi.org/10.1016/j.agwat.2006.06.018 